\title{
Leprosy in 18-month-old children, Bichena District, Gojjam Administrative Region, Ethiopia
}

\author{
ELISABETH FEKETE \& TADELE TEDLA \\ National Leprosy Control Programme, POBox 5033 Addis \\ Ababa, Ethiopia
}

Received for publication 8 June 1982

Summary In a mass survey of leprosy in Bichena District, Ethiopia, where a total of 814 new cases were detected, 2 cases of borderline-tuberculoid (BT) leprosy were discovered in children aged 18 months. Although incubation periods of less than 2 years are generally considered extremely rare, this finding emphasizes that young children under 2 years of age should not be excluded from leprosy surveys in endemic regions.

\section{Introduction}

A report on leprosy in children ${ }^{1}$ states that the average incubation period (or interval between exposure to infection and the first recognizable symptoms) is $2-5$ years, and leprosy cases in children below 2 years are exceedingly rare. In studies ${ }^{2}$ on the life history of 462 children born at Kalaupapa Settlement on Molokai and living under a variety of conditions of early exposure to leprosy, it was concluded that living continuously with an untreated lepromatous parent results in leprous infection in about $40 \%$ of such children, with onset of symptoms between 5 and 14 years of age.

\section{Objectives}

One of the main objectives of the mass survey which was conducted between 1 February and 14 May 1981 in Bichena District, Gojjam Administrative Region, Ethiopia, was to find leprosy cases as early as possible and put them under regular treatment. 


\section{Patients and methods}

Leprosy case detection was carried out in 231 localities of Bichena District with a total population estimate of 235,700 .

A population count was conducted by focal point survey where all the individuals in the community were gathered at a central place for systematic physical check up. The focal point survey was supplemented by a house-tohouse survey.

\section{Results}

Eight hundred and fourteen new cases were detected during the survey, 168 (21\%) falling in the 5-14 age group and $12(1.5 \%)$ in the $1-4$ age group. Among the 12 cases two children of 18 months were found to have borderline-tuberculoid (BT) leprosy.

The first child, a female, had a mother who had been diagnosed 7 months previously as suffering from borderline leprosy and had been treated with dapsone $100 \mathrm{mg}$ daily. The child had never visited a clinic before the date of the survey, 20 February 1981. Her father was healthy. The parents stated that the child's skin lesions had been present for 5 months, and examination revealed a number of hypopigmented macules on the back, arms and buttocks. A biopsy was taken from an active lesion, and the report from ALERT, Addis Ababa, stated: 'There are multiple small collections of epithelioid cells, lymphocytes, plus a few Langhans type giant cells, throughout the mid-dermis. No AFB seen. Opinion: BT leprosy.'

The second child, a boy, also 18 months old, had a lepromatous father who had been on treatment with dapsone during the previous 10 years, but the mother was healthy. The oldest child in the family, a girl of 10 years, was found at the time of the survey to have tuberculoid (TT) leprosy. The fact that the mother had no leprosy excluded any question of intra-uterine transmission. Examination of the boy revealed hypopigmented macules on both upper arms, buttocks and legs. He was sent to ALERT for further investigation where a diagnosis of borderline-tuberculoid (BT) leprosy was confirmed.

\section{Discussion}

In spite of the generally held view that in leprosy an incubation period of less than 2 years is extremely rare, we were able to find two children of 18 months suffering from leprosy out of a total of 814 patients diagnosed in the survey, an incidence of $0.24 \%$. This finding emphasizes that young children under 2 years of age should not be excluded from leprosy surveys in endemic regions. 


\section{Acknowledgements}

We are indebted to the staff of Armauer Hansen Research Institute Laboratory for preparing the biopsy, and to Dr J Warndorff for reading the result.

\section{References}

1 Noussitou FM, Sansarricq W, Walter J. Leprosy in children, WHO 1976.

2 Arnold HL, Fosal P. Leprosy diagnosis and management. 2 edn. 1973.

3 Job CK, Selva Pandian A J, Kurian PV Leprosy diagnosis and management. 1974. 